ÉGYPTE monde arabe

\title{
Égypte/Monde arabe
}

16 | 2017

L'État égyptien en quête de stabilité

\section{The Fight over Institutions in Post-Revolution Egypt}

\section{Mustapha Kamel al-Sayyid}

\section{(2) OpenEdition \\ Journals}

Electronic version

URL: https://journals.openedition.org/ema/3714

DOI: $10.4000 /$ ema.3714

ISSN: 2090-7273

\section{Publisher}

CEDEJ - Centre d'études et de documentation économiques juridiques et sociales

\section{Printed version}

Date of publication: 15 October 2017

Number of pages: $59-76$

ISBN: 2-905838-95-7

ISSN: 1110-5097

Electronic reference

Mustapha Kamel al-Sayyid, "The Fight over Institutions in Post-Revolution Egypt", Égypte/Monde arabe [Online], 16 | 2017, Online since 15 October 2019, connection on 07 July 2022. URL: http://

journals.openedition.org/ema/3714 ; DOI: https://doi.org/10.4000/ema.3714 


\section{THE FIGHT OVER INSTITUTION IN POST-REVOLUTION EGYPT}

\section{ABSTRACT}

This paper examines the fight over a new institutional order in post-January Revolution Egypt. It traces institutional change since the ousting of Hosny Mubarak on February 2011. It uses the historical institutionalism theoretical framework in order to illuminate understanding of this process of institutional change during three phases, namely: rule by the Supreme Council of the Armed Forces (February 2011-June 2012) by the Muslim Brotherhood (MB) (June 2012-June 2013) and since the overthrow of that rule on July 3, 2013. It situates this institutional change within the context of a struggle for power among the three forces that took part in the January Revolution, namely the armed forces, the MB and the revolutionary youth, delineating major issues in this fight. It explains the authoritarian choices of the first two actors in terms of their strategic calculations, unintended consequences, path dependency and past cultural traditions. It brings to light the negative implications of this shaky institutional structure for the search for social justice in Egypt.

The paper departs from usual concerns of New-Institutionalism by focusing more on the creation of institutions than on their functioning and impact on behavior of people subjected to them. It attaches great importance to asymmetry of power among social and political actors as an important explanatory variable of their coming into being and their demise.

\section{INTRODUCTION}

A revolution is, by definition, the expression of a wish to reject institutions of an old order and to replace them with new institutions likely to give shape to a new order. As the January Revolution of 2011 in Egypt is the subject of 
much controversy, we will use cautiously the term "institutional change," and not "institutional reform" or "upheaval," to describe this process. We will define institutions as "the formal or informal procedures, routines, norms and conventions embedded in the organizational structure of the polity or political economy....[which] can range from the rules of a constitutional order or the standard operating procedures of a bureaucracy to the conventions governing trade union behavior or bank-firm relations." ${ }^{1}$ The historical institutionalist approach adopted in this paper associates institutions with organizations and the rules or conventions promulgated by formal bodies. ${ }^{2}$

In this sense, there has definitely been much institutional change in Egypt following the January 2011 Revolution. In fact, the first controversy that divided the political forces leading the revolution- what constitution to adopt - was an institutional issue. Thereafter, every phase of the political evolution was associated with a new constitutional document. Also, the institutional change was not limited to the drafting of constitutional documents. Different laws, particularly those related to political parties and elections, also accompanied each phase of the post-revolution period. This paper is not only concerned with an account of institutional change in Egypt since February 2011, but also ventures to explain the choices that ended up favoring one type of institutions. It also inquires what purposes such institutional change served and, in particular, whether it contributed to the promotion of social justice, one of the slogans of the January revolution.

The paper is set within the framework of New Institutionalism and, more particularly, one specific trend within the New Institutionalist school: Historical Institutionalism. The other two trends are Rational Choice Institutionalism and Sociological Institutionalism. Historical Institutionalism traces the history of institutions as divided into phases, each marked by specific structural features, and offers a broad framework for analysis of the impact of institutions on individual behavior, including both culture and strategic calculation. It also attaches considerable importance to the role of ideas in institution creation, while remaining open to complex explanations including other factors. Asymmetries of power relations play a considerable role in its explanatory framework. ${ }^{3}$

Rational Choice Institutionalism stresses the importance of property rights, transaction costs and rent-seeking to the functioning of institutions. Its followers usually assume that actors are guided by a specific set of preferences or tastes. They view politics through the prism of collective action dilemmas, with individuals confronted by a suboptimal outcome of their preferences, due to the choices they face. These outcomes may result from strategic

1. Hall P. and Taylor R. 1996, p. 6-7.

2. Ibid.

3. Examples of scholars using Historical Institutionalism: Evans, P. et al. 1985, Bringing the State Back. New York: Cambridge University press ; Krasner, S. 1980, Defining the National Interest. Princeton: Princeton University Press. 
interaction based on expectations of what other actors would do. ${ }^{4}$ Sociological Institutionalism understands organizations within their own cultural setting, leading to the idea that the same institution operates differently in other cultural settings. A liberally-framed constitution, for example would operate differently in a country like Egypt than in a country like Belgium, due to differences in local culture between the country of origin and the country of implantation. ${ }^{5}$ The conceptual arsenal of this trend is not limited to formal rules, but also includes norms, symbol systems, cognitive scripts and moral templates. In the words of Hall \& Taylor, the latter provides "frames of meaning guiding human action." ${ }^{6,7}$

This paper follows the Historical Institutionalism trend because of its broad analytical framework and its emphasis on asymmetry of power relations, which proved to be crucial in the process of institutional change in Egypt. However, the paper treats institutions not as influencing the behavior of the actors, but as objects of competition, fighting and even manipulation among political actors, with the outcome of this competition being decided by the distribution of utilitarian, normative and coercive political resources among actors and their skills in using these resources.

This paper is thus divided into three parts: the first describes the process of designing and drafting institutional rules, embodied in constitutional and legal documents; the second strives to offer an explanation of the choices that were made with respect to the design of these institutions; and the third attempts to offer an interpretation of institutional change in Egypt using selective concepts of Historical Institutionalism.

\section{THE PROCESS OF INSTITUTIONAL CHANGE}

Three major political forces were involved in the events of the January Revolution, namely the youth revolutionary groups, the $\mathrm{MB}$ and the military. The balance of power among these actors shifted in three main phases.

4. Immergut, E. 1992, Health Politics: Interests and Institutions in Western Europe, New York: Cambridge University Press ; Hattam, V. 1993, Labor Visions and State Power: The origins of Business Unionism in the United States, Princeton: Princeton University Press.

5. Hall P. and Taylor R. 1996

6. Ibid., 14.

7. Swidler, A. 1986, "Culture in Action: Symbols and Strategies," American Sociological Review, n 51, p. 273-286; Cook, K. and Levy, M. (eds), 1990, The Limits of Rationality, Chicago: Chicago University Press. 
The first phase (February 11, 2011 - June 30, 2012)

During this phase, the Supreme Council of the Armed Forces (SCAF) monopolized all power. Several civilian cabinets governed the country prior to the handover of power to an elected president on June 30, 2012, but the final decision-making authority remained in the hands of the SCAF. The fall of Mubarak's regime, the outlawing of the former dominant National Democratic Party and the physical and moral breakdown of police forces during the days of the Revolution allowed all political forces in the country to operate freely and to compete with each other for control of the streets and, indirectly, of state power.

The SCAF sought, in the early months of the Revolution, to reach an understanding with the $M B$ and the Salafists, but, becoming increasingly apprehensive about the possible Islamization of the state by these groups, it tried thereafter to adopt supra-constitutional principles stressing the civil nature of the state. ${ }^{8}$ Such an attempt turned the Islamists against the SCAF which, faced by the combined opposition of Islamists and revolutionary groups, succumbed to pressure by abandoning the document.

During this phase, major decisions with institutional implications were largely initiated by the SCAF. Thus, the Constitutional Declaration of March 30, 2011 was very important, as it contained articles that impacted the trajectory of the interim period. Although most of its 63 articles copied similar articles in the amended 1971 constitution, it identified the SCAF as the dominant organ for the exercise of governmental authority during this period. A concrete example of this was Art. 356 of the Constitutional Declaration, which endowed the SCAF with legislative and executive power. These powers would be conceded by the SCAF to a parliament and president, once elected. The Declaration maintained the bicameral legislature inherited from the constitution of 1971, but created an electoral commission to supervise elections of both the legislature and the president.

Two other institutional developments under the rule of the SCAF had far-reaching implications for Egyptian politics: the banning of the National Democratic Party (NDP), which had dominated the political scene since 1977, and the authorization of the formation of politico-religious parties. The first development followed a decision by the Political Parties Chamber of the Supreme Administrative Court of the Council of State on April 16, 2011, which disbanded the NDP for its corruption of political life. The emergence of politico-religious parties became possible thanks to an amendment to the Law of Political Parties, which had originally been adopted under the late president Anwar El-Sadat in 1977. The law had laid out conditions for the establishment of political parties, including a ban of parties based on religious grounds. The amended version (Art. 5) of Decree Law Number 12 for 2011,

8. El-Selmi, A. 2013, p. 101-103; Rabei', A.H. 2012, p. 25-29. 
maintained this condition in Article 4-3, but spelled out what religious grounds would mean. It also transferred the authority to approve the formation of new parties from a politically-dominated body to a committee made up entirely of judges. ${ }^{9}$ The new committee interpreted the amended Art. 4 in an extremely liberal manner, thus approving the formation of more than a dozen politico-religious parties, all calling for the strict application of Sharîa. The most important of these parties was the Freedom and Justice Party, the political arm of the MB, and the Nour Party, which gave a political voice to Salafist groups in Egypt for the first time. These developments paved the way for the participation of these parties first in the legislative elections of both the People's Assembly and the Shura (Consultative) Council in late 2011 and early 2012, and later in the presidential elections of May-June 2012. Candidates of these parties won both elections by massive majorities, with Mohammad Morsi of the MB elected as President of the Republic in June 2012. ${ }^{10}$

The new electoral law was a mixed system, combining proportional representation for two-thirds of the seats and majority rule for one-third in the two houses of the bicameral legislature. Party candidates were initially limited to lists competing for two-thirds of the seats, but the SCAF later decided, presumably under pressure from political parties, to allow them to compete for the remaining third. This concession to political parties later proved to be a fatal action for the new assembly, as it led the Supreme Constitutional Court on June 12, 2012 to rule that the electoral law itself was unconstitutional. The Court argued that such a provision violated the fundamental constitutional rule of equality for all citizens. This provision presumably discriminated against nonparty citizens, indeed the majority of voters, whose representatives would have to compete even for this third of the seats with party candidates.

The most controversial act of the SCAF was definitely its adoption of the Supplementary Constitutional Declaration of June 17, 2012, which aimed to maintain its presence as a supra-governmental body even after the election of a new president, limiting the latter's power over important matters. The Declaration required the new president to seek approval from the SCAF before declaring a state of emergency or a state of war and endowed the SCAF with full legislative powers until the election of a new legislature, as well as full control over all matters related to the armed forces. This action sowed the seeds of a clash with the new president even before he assumed power. ${ }^{11}$ Nevertheless, it must be recognized that the four electoral consultations that

9. Amiriyyah-Official Press, 1991, p. 106, http://www.parliament2011.elections. eg 10. The website Ana Al-muslim -I am the Muslim- published a list of twelve parties recognized as Islamist parties. These were: Freedom and Justice Party, The Nour, Al-Asâla, The Wasat, Al-`Amal, Misr Lil-Bana', Al-Salâm wal-Tanmiyya, Al-Nahda, Jabhat al-Islâh, Al-Tahrîr Al-Islâmi, Al-Hadâra, and al-Bana' wal-Tanmiyya (http://www.muslim.org).

11. Text of the SCD, Al-Jarîda Al-Rasmiyya, quoted in Al-Shorouk, June 16, 2012. 
took place under SCAF rule were all fairly conducted and open to all political forces and independent candidates.

The second phase (June 30, 2012 - June 30, 2013)

This phase corresponds to the one-year rule of the MB, which succeeded in electing one of its leaders to the post of President of the Republic. The MB won with a $52 \%$ majority in the second round of elections in June 2012, and controlled the Shura Council- the upper house of the parliament that remained in office following the dissolution of the People's Assembly.

The most important institutional changes introduced by the $\mathrm{MB}$ were the following:

1-Paving the way for a new pattern of civil-military relations, with elected civilian government leaders having the upper hand;

2-Drafting a new constitution stressing the role of Sharîa as a framework for the exercise of all rights;

3-Issuing a constitutional declaration that put the head of the state beyond any accountability.

The first of these changes proved to be short-lived. Morsi, the elected president, wanted to bring the armed forces under civilian control. On August 12, 2012, after roughly six weeks in power, he ordered the retirement of the defense minister, Field Marshal Hussein Tantawi, as well as of the Chief of Staff of the Armed Forces, General Sami Enan, and revoked the Constitutional Declaration adopted by the SCAF on June 17, 2012. He also appointed a new defense minister and a new Chief of Staff of the Armed Forces, namely Generals Abdel Fattah El-Sisi and Sidqi Sobhi (Brown, N. 2012). Nevertheless, the armed forces soon enacted their autonomy vis-à-vis the civilian president. On June 23, 2013, they issued an ultimatum to all politicians in the country to settle their differences. However, none of these individuals were willing to bridge the gap that separated them, even in a situation that threatened the country with civil war. Morsi was subsequently removed from his post on July 3, 2013. ${ }^{12}$

The second attempt at institutional reform was the adoption of a constitution drafted by the Constituent Assembly. The process of forming this assembly was marred by disputes from the very beginning. Two assemblies had been

12. Mona El-Kouedi, March 12, 2013; It should be stressed, however, that Morsi did not want to strip the military of all privileges. The 2012 constitution left the military budget completely in the hands of the National Defense Council. This Council was also to be consulted about all draft laws related to the armed forces (Art. 197). Another provision insisted that the defense minister was the Commander-in-chief of the Armed Forces and was to be appointed from among its officers (Art. 195). A third article gave the military courts the authority to try civilians if they committed any act harmful to the armed forces (Art. 198). 
formed during 2012. The first was elected in a joint meeting of the two houses of parliament on March 24, 2012. It was made up of one hundred members, half of whom were members of parliament. On April 10, the Administrative Judiciary Tribunal of the State Council ruled that the composition of the Assembly was unconstitutional because Art. 60 of the Constitutional Declaration was interpreted by the Tribunal to mean that its members should be elected by the Parliament, but should not themselves be parliamentarians.

Another attempt was made by the parliament on June 13, 2012, with a second assembly made up of one hundred members, thirty-five of whom were non-Islamist. Non-Islamist groups did not approve of this balance and filed a suit before the Administrative Judiciary Tribunal (AJT) on September 25, 2012. The AJT eventually rejected their demand to outlaw the assembly, on October 23, 2012. However, Morsi, concerned that renewed attempts by these groups might invalidate the work of the second assembly as well as the elections of the Shura Council itself, issued on November 22, 2012 a constitutional declaration endowing himself with powers above the law. The declaration banned legal suits against all constitutional declarations, laws or decrees that he had issued since he assumed his post and until the election of a new People's Assembly (Art. 1). By virtue of this declaration, the then Public Prosecutor who had been in his post since the time of Hosny Mubarak was removed and replaced by a new one (Art. 3). Finally, the Declaration banned any judicial ruling calling for dissolution of the Shura Council and the Constituent Assembly (Art. 5) ${ }^{13}$. The vehement opposition to this declaration led Morsi to annul it on December 8, 2012, while maintaining its legal effects.

The Constituent Assembly, which did not heed the demands of the opposition, started its meetings on June 18, and announced its final draft on November 30, 2012. The draft was put to referendum on December 15, 2012 and was approved by $63.8 \%$ of voters. Non-Islamist parties called for a boycott of the referendum. The turnout rate was $32.9 \%$, far less than the turnout in previous elections after the January Revolution. There is no doubt that the Constitution of 2012 was a much more advanced document compared to pre-revolution constitutions, as it lifted many restrictions on the exercises of civil and political rights, and strengthened powers of the cabinet vis-à-vis the president. According to this constitution, the latter was entitled to exercise his authority directly over matters related to defense, security and foreign policy, leaving all other matters to the Council of Ministers. However, it was severely criticized by non-Islamists for the heavy emphasis it put on Sharîa as a limit on the exercise of all rights (Art. 2, 10, 11, 81 and 219), and the role it assigned to religious institutions, particularly al-Azhar (Art. 4). ${ }^{14}$

13. http://gate.ahram.org.eg/NewsContentPrint/1/1/127/275479.aspx

14. Brown, N. October 10, 2012; GOE., Constitution of 2012; Brown and Lombardi, December 2012; Steuer, C. and Blouet, A. 2015, p. 236-256. 
The third phase (after June 30, 2013)

This constitution with Islamist features did not remain in force for long. Following massive popular demonstrations and counter-demonstrations beginning on June 30, 2013, President Morsi was overthrown on July 3. A statement was made that same day by General Abdel Fattah El-Sisi, then defense minister, explaining the conditions that led the army to remove the president and defining the road map for the interim period.

That statement was followed by two declarations by the Interim President Adly Mansour, one on July 6 dissolving the Shura Council, and another on July 9 outlining a constitutional framework for the interim period. The El-Sisi statement, known as the Road Map, promised the following:

-New parliamentary elections;

-The formation of a committee to amend the 2012 constitution;

-New presidential elections;

-The formation of a higher commission for national reconciliation and empowering youth in government.

The Constitutional Declaration of July 8 set the legal basis for the interim period. Interestingly enough, its first article referred again to Sharîa, copying most of the text of the controversial Art. 219 of the Constitution of 2012. This was perhaps meant to accommodate the Salafists, who had been the driving force behind the article, but whose leaders had come out in support of the new order. Other articles endowed the interim president with executive and legislative powers and the authority to form a council of ministers to rule the country during this period (Art. 24, 25). The Declaration also allowed for the setting up of a committee of ten legal experts chosen by their respective institutions to look into possible amendments of the constitution of 2012 and to present these amendments to the Committee of Fifty, which would then consider and approve these amendments and put them to referendum (Art. 28, $29,30)$. The Committee of Fifty was to include representatives of political parties, intellectuals, professional associations and functional unions, public personalities, specialized national councils, al-Azhar, Christian churches, armed forces and the police. Each of these bodies was to choose its representatives, leaving to the Council of Ministers the task of selecting public figures. The Declaration required that at least ten members of the committee be young people and women. Following the approval of the new amended constitution, the president was to call for the election of a new parliament within fifteen days (Art. 30) (for the details of these events and texts of these statements and declarations, see http://www.sis.gov.eg).

The Interim President announced names of members of the Committee of Fifty on September 1, 2013. The Committee started its meetings on September 8 and elected as its president Amr Mossa, who was the former Secretary General of the Arab League and Minister of Foreign Affairs, as well as a presidential candidate in 2012. Apart from five persons representing major Egyptian political affiliations- Islamists, Liberals, Arab Nationalists and 
Leftists- and ten public figures, most of the members of the committee came from specific professional associations or institutions of state and society.

The final product of the committee, namely the amended constitution of 2014, approved in a popular referendum held on January 16, 2014, reflected the relative power of the different components of the committee as well as their occupational or corporatist backgrounds. Representatives of religious institutions persuaded other members to oppose any reference in the preamble of the constitution to "dawla madaniyya" ("civil state"). The Committee had to accept the alternative formulation of this concept as civil governance. The influence of the secular members is to be found in Parts 3 and 4 and in the suppression of excessive references to Sharîa (Art. 4 and 219 of the 2012 Constitution).

In examining the institutional impact of the debates within the Committee of Fifty, one can discern a competition among three forces, each trying to shape the evolution of the country according to its own conceptions of the right political and social order, as well as its own specific interests. These three forces can be identified as expressing authoritarian, liberal and corporatist outlooks of this order. Their institutional impact can be seen in the rules and practices governing the following areas:

\section{Civil-Military Relations}

The ideal liberal orientation of civil-military relations calls for the supremacy of civil authorities over military institutions, while the authoritarian orientation maintains a large degree of autonomy for the latter. The 2014 Constitution tilts heavily in favor of the authoritarian orientation. This can be seen in several articles. Art. 201 insists that the defense minister is the Commander-in-chief of the Armed Forces and is to be appointed from among active army officers. Art. 234 adds that, for the following presidential term, he should be approved by the National Defense Council (eight out of fourteen members of which are to be army officers). Also, this Council is to approve the military budget, which is included in the state budget as one line, with no details disclosed, and its consent is required for the declaration of war (Art. 203). Finally, although Art. 204 strove to limit the trials of civilians before military courts, it allows for a large number of such cases, such as assaults on military installations, equipment or military personnel. Police officers also gain a good degree of autonomy, as Art. 207 provides for the establishment of a Supreme Police Council that should be consulted on all matters related to the police. Some of these provisions were included in past constitutional documents, but this constitution was the first to endow the National Defense Council with the authority to approve the appointment of the defense minister.

Neither this constitution nor the election of Abdel-Fattah El-Sisi turned Egypt into a military regime in the formal sense of the term, for Egypt's government continues to be run mostly by civilian technocrats. However, standard operational practices gave the armed forces a prominent role in the country's politics, economy and media. Major initiatives on El-Sisi's part, such as building a new capital, cultivating one-million-and-a-half acres of desert land and 
designing a new network of roads, did not originate in any civilian ministry. It is also normal for the Chief of General Intelligence Services and the head of the Administrative Control Authority- both former army officers- attend important meetings held by the presidency to discuss national issues, ranging from the security situation to the economy. El-Sisi usually makes important speeches at military meetings, often called informational seminars of the armed forces. Although the president has appointed a good number of advisory bodies on matters ranging from economic development to education and scientific research, these councils rarely meet.

The second rank of senior government officials below the cabinet includes the country's twenty-seven governors, who run Egypt's various provinces. Out of the eleven governors appointed in December 2016, four were military and five were police officers. Nine months later, six new governors were named, five of whom were also military and police officers. Two months later, four new governors were appointed on the occasion of forming a new cabinet, two of whom were army officers, and two of whom were medical doctors. As of June 2017, nineteen of twenty-seven governors were either military or police. ${ }^{15}$ Eyewitnesses have confirmed that intelligence and security services were active in selecting people to become candidates in parliamentary elections. ${ }^{16}$ Nearly 84 members of the new House of Representatives, elected in 2015, are former army and police officers, several of whom have became chairs of important assembly commissions. The first head of Coalition Fi Hobb Masr (For the Love of Egypt), which declared itself in full support of President El-Sisi, was a former intelligence officer. Several heads of the newly formed parties were also former army officers, the most famous of which was the Humat Al-Watan (Motherland Protectors) Party, led by Major General Galal Haridi, who came as the fourth party in terms of membership of the new House of Deputies. ${ }^{17}$

When the country faces shortages of goods or medicines, the military step in to supply baby milk and pharmaceuticals. This expanding economic role of the armed forces has provoked angry whispers among business people. The military establishment is also active in shaping the minds of the Egyptian people. The president, not satisfied with what he considered to be unfriendly media, terminated the contracts of several independently-minded anchors of televised talk shows on private television channels. Anchors of talk shows were advised to include a former military or police officer on all talk shows, to be introduced as a strategic expert. Security services came to own a majority share in private television channels and established their own television

15. Ahramonline, December 25, 2015; September 7, 2016; February 16, 2017.

16. Hazem Abdel Azim, http://www.masralarabia.com, January 2016.

17. http://www.almasreya.com, December 12, 2015; http://www.tahririnews.com, December 6, 2015. 
channels, known as DMC. The DMC's launch was preceded by a very expensive media campaign. ${ }^{18}$

\section{Relations within the Executive Branch}

Due to the fragility of political parties in the post-revolution period, constitution-makers oriented themselves toward a semi-presidential system modeled along the constitution of the Fifth French Republic. While an authoritarian orientation would tend to distribute powers between the president and the prime minister in favor of the former, a liberal orientation would call for the opposite.

A comparison between the two constitutional documents of 2012 and 2014 suggests important differences between them. Both called for an elected president who would serve only two consecutive terms, each lasting four years. Both also conferred vast powers on the president. According to the 2014 constitution, the latter appoints the prime minister, with the agreement of the assembly. If parliament members disagree with the president's choice, the latter has to appoint a prime minister nominated by the party or the coalition that has the majority in the House (Art. 146). This article limits the president's freedom of choice, compared to the formulation of Art. 139 of the 2012 constitution, which gives the Parliament the liberty to choose the prime minister only as a third option, if the president's first choice and the candidate from the majority party designated by the president both fail to get approval from the House within thirty days.

In addition, the president shares with the Council of Ministers the formulation of public policies. The President has the authority to form the cabinet (provided it meets with approval by the House of Representative), and he could ask for a cabinet reshuffle in consultation with the Prime Minister. On matters of legislation, he was empowered to propose laws and promulgate them. In foreign affairs the President could conclude treaties and represent the country in foreign relations. He could declare a state of emergency with the approval of the parliament, pardons or alleviates court sentences. Finally he is the supreme commander of the armed forces.

But the two constitutions differ on how the president is to exercise his powers. Art. 141 of the 2012 constitution takes a liberal stand on this issue, limiting the direct exercise of power by the president to matters related to national defense, security and foreign relations. This article was dropped in the amended 2014 constitution due to the strong demand of leaders from the Tamarrod movement in the Constituent Assembly ${ }^{19}$ (Art. 132-154, 2012 constitution, Art.

18. Soleiman Gouda, Al-Hayât, January 25, 2017, p. 16 for a counter-claim.

19. Tamarrod (Rebellion) is the movement initiated by young people who succeeded in getting presumably millions of Egyptian citizens to sign a petition calling for new presidential elections in the Spring and Summer of 2013. The movement was later seen to be pro-military and gradually disappeared from the public scene in Egypt following the election of Abdel Fattah El-Sisi as president. 
139-162, 2014 constitution). President El-Sisi understands the Constitution as giving him the authority to exercise all executive powers without involving the prime minister. This practice was not lost on Egyptian commentators, who described the prime minister as a secretary of the president. ${ }^{20}$

\section{Composition of the legislature}

The legislature of the country had been a bicameral entity since the constitutional amendments of President Sadat in 1980, which added a second chamber, known as the Shura Council. The original lower chamber had its name changed from "the People's Assembly" in 1971 to the "House of Representatives" in the 2012 constitution and its amended 2014 version. The Committee of Fifty decided, after a very heated debate, to abolish the Shura Council, establishing a unicameral legislation.

In both the 2012 and 2014 constitutions, the lower house is given full parliamentary powers over finance, legislation, oversight and organizational matters. It has also the power to approve the formation and reshuffling of the cabinet and to censure ministers, individually and collectively, through proposing a vote of confidence (Const. 2012, Part. III, Ch. 1; Const. 2014, Part. V, Ch. 1).

4. Theoretical basis of political representation in the People's Assembly

Those who drafted the Law of the House of Representatives in Egypt wavered between the two theories of parliamentary representation: is the MP a representative of those who elected him, or a trustee of the nation? The vast majority of the MPs (540), whether elected from single member districts (420) or collectively on closed lists (120), are not bound to limit their interventions in the parliament to issues of local or regional concern. They are therefore trustees of the nation. This is particularly expected of the $5 \%$ members who are appointed by the President of the Republic, and who do not belong to any particular geographic area or a functional group. These 28 members include academics, writers, athletes and Christians. ${ }^{21}$

With political parties accounting for less than half of the membership of the House of Representatives (250 out of 598 deputies) and with these parties for the most part lacking any distinct platform or ideology, members of this assembly behaved mostly as delegates of their constituencies, reflecting in their interventions and email messages issues that were of interest only to their local constituencies. The quotas allotted for these groups reflect a corporatist view of legislature membership. 


\section{AN ATTEMPT AT INTERPRETATION}

Major disputes among the political forces in Egypt shaped institutions following the 2011 revolution. These disputes, through which new institutions came into being and later disappeared, built the new institutional order on a shaky foundation. Most of the institutional initiatives were divisive in nature, lacking consensus among major political forces. Once a new institutional initiative was introduced, opposition would mobilize to undermine it through protests, legal action before the courts, or even calling on the armed forces to intervene and remove those who had authored it. In addition, the creators of these institutions acted in ways that threw their credibility into doubt (constitutional declarations on March 30, 2011, June 17, 2012, and November 22, 2012). Indeed, some laws and practices that were intended to implement articles of the constitution depart from the spirit or even the letter of these articles, turning them into empty words. This is the case with Law-Decree Number 83 of 2013, which freed law enforcement agents of any responsibility for actions undertaken in their efforts to combat terrorism. Also, an amendment to the code of criminal procedures issued under Interim President Adly Mansour extended almost indefinitely the period of provisional detention. This allowed security authorities to arrest and detain thousands of people suspected of being MB supporters. Law Number 107 of 2013 on public meetings, marches and political demonstrations contravened the constitution by requiring prior authorization from the Ministry of Interior for any demonstration, while the constitution had only required organizers of such demonstrations to inform the ministry of their intentions beforehand. It also imposed heavy penalties on those who ignore its provisions. ${ }^{22}$

To these laws, President Abdel Fattah El-Sisi added the Law of Terrorist Entities and Terrorists Number 7, 2015 which complemented the penal code by enabling restrictions on the freedom of movement and confiscation of property belonging to terrorists and banned terrorist organizations. The definitions it offered for terrorist entities and terrorist acts were too broad and went beyond what is normally considered to be terrorist activity. ${ }^{23}$ Another law considered public buildings guarded by the army to be military institutions, thus making any damage to these buildings and installations a crime to be referred to military tribunals. ${ }^{24}$ In line with these laws, the government considers to be legal its banning of the $M B$, as well as its confiscation of assets and properties belonging to NGOs and individuals affiliated with the MB, despite rulings to the contrary by the Administrative Court of the State Council.

There is little doubt that the institutional changes that took place in Egypt after February 2011, and particularly after July 2013, moved the country away from the four goals of the January revolution: Freedom, Bread, Social Justice

22. Al-Jarîda al-Rasmiyya, $\mathrm{n}^{\circ}$ 47, November 24, 2013.

23. Al-Jarîda al-Rasmiyya, $\mathrm{n}^{\circ}$ 7, 53, February 17, 2015.

24. Al-Shorouk, June 1, 2017. 
and Human Dignity. This paper has pointed to the asymmetrical distribution of power among the three main political forces: the military possessing mostly coercive and normative power, the Islamists possessing normative and utilitarian power, and young revolutionaries initially possessing normative resources, which were largely diminished after the fall of Mubarak, and very few utilitarian or coercive resources. Historical Institutionalism adds three useful interpretative concepts to power relations: strategic calculation, unintended consequences, and path dependence. It also brings into play the power of ideas, and political culture in particular.

According to this school, a rational actor in politics is guided by his final goals and reasonable expectations of how to reach them. All the major actors of the January Revolution made strategic calculations, but some lacked reasonable expectations of how to attain their goals. The first collective actor to err in its strategic calculations and to lose a power struggle after the revolution was the group of young revolutionary people. Believing that the masses would back them, as they did during the eighteen days of the revolution, they continued their protests and occupation of Tahrir Square, without realizing that those masses were tired of the state of disorder and insecurity in the country, and particularly of the economic slowdown, which deprived many people of their jobs or a decent income. Young revolutionaries were therefore the first to lose the fight over shaping new institutions in the country. The cause of their failure was simply the belief that what worked in the past would also work in the present. They called for mass mobilization on the eve of the January Revolution and millions of people followed them. However the calls for mobilization following the fall of Mubarak rarely delivered what young revolutionaries expected. Path dependence led them nowhere. The institutional framework had changed and what could be an effective call for a revolution under Mubarak failed to produce the same effect under the SCAF.

The MB mistakenly calculated that it could rule the country alone, relying on its electoral victories and capacity for popular mobilization. It possessed utilitarian resources and limited coercive resources, which it used to intimidate protesting revolutionary youth. It also counted on the normative resources gained by invoking the goal of establishing a Caliphate, i.e. an Islamic Order guided by the principles of Sharîa. The MB's strategic goal shifted in the early months of the post-revolution regime from gaining legitimate status and forming a political party to ruling the country alone. As such, it put up a candidate in the presidential election of 2012, despite the fact that it had previously declared that it would have no candidate in the election. This in itself was a strategic error, as its leaders had spent many years in jail and were ill-prepared to govern the country. Its other error was not to try to win a majority of people to its side and ignoring the fact that it gained the presidency thanks to votes from non-Islamists. Instead of keeping this majority or even attempting to enlarge it, the MB alienated Salafists and non-Islamists alike by relying exclusively on its own forces to govern the country. The Salafists and the non-Islamists who were appointed as advisors to President Morsi either resigned or were dismissed. Another strategic error was the belief that the MB 
could keep the armed forces away from power. Actually, the utilitarian, coercive and normative resources of the $\mathrm{MB}$ were no match to the repressive power of the Egyptian armed forces and police, backed also by massive popular support in a polarized country. The strategic calculations of MB evolved from occupying a legitimate position in the country's politics to governing the country. But it did not have realistic expectations of its preparedness to govern, its capacity to maintain people's support, or of its ability to prevail over state institutions, namely the army, police, judges and bureaucracy. ${ }^{25}$

The only actor that did not fail so far in its strategic calculations was the army, which managed to adapt to new situations, to offer tactical conditions when the popular pressure mobilized by either of the other two forces was too great, and to wait for the right moment to strike. The army's leaders wanted to emerge in post-revolution Egypt as the undisputed masters of the political scene. They thought they could do this by having the Islamists- MB and Salafists- as junior partners. When this approach did not work, they agreed to call for elections and even to allow a Muslim Brother to ascend to the presidency. They also allowed the new president to remove on August 12, 2013 their commander, Field Marshal Hussein Tantawy, and to dissolve the SCAF. However, the MB-appointed defense minister waited for the right moment to retaliate against the $M B$, putting an end to their brief journey into power by taking advantage of their strategic errors, which isolated them from important public contingents. This new situation not only allowed the armed forces to run the country unopposed, but also to extend their power to areas where they had little presence before the January Revolution, such as the media and even education, in addition to extensive engagement in economic activities. The armed forces did not want to share power with either of the two other political forces, and knew how to concede temporarily when the wind of support turned either towards the young revolutionaries or the $\mathrm{MB}$ (the spring of 2011 for the former and June 2012 for the latter). They waited for these other forces to make judgment errors, in order to reinforce their position and to monopolize the levers of power.

One can clearly see that the actions of both the revolutionary young people and the $\mathrm{MB}$ led to consequences that were completely the opposite of what they had intended. Calls for popular mobilization by the revolutionary young people, when repeated following the fall of Hosny Mubarak, did in fact alienate the fatigued masses. The MB's turn at governance did not increase its popularity or move towards the establishment of an Islamic Caliphate. Rather, this decision starkly revealed the MB's incompetence and incapacity to govern, turning large numbers of the people who had voted for the MB against it, less than one year after it had assumed highest level of power.

Four great ideas inspired the actions of all these actors and of specific groups of people behind them. The belief that "Islam is the solution" brought

25. Brown, N. 2013, p. 45-58. 
millions of $M B$ sympathizers to the streets and to voting booths, aiming to bring $\mathrm{MB}$ candidates to the Parliament and the Presidential Palace. In February 2011 and in June 2013, this idea ceased to be hegemonic. It gave way to another idea, namely that the armed forces were the nation's savior. At a moment of crisis, Egyptian people looked to the army to get the country out of trouble. As it had in July 1952, following a period of government instability and major riots in downtown Cairo, the armed forces brought an end to the dramatic events of January-February 2011. The army was called upon again in June 2013, when opposed factions were gathering less than one kilometer away from each other in what seemed to be a civil war situation. Those in Rab`a al-`Adawiyya Square wanted to keep Morsi as president, and those who surrounded the presidential Ittahadiyya Palace, were fed up with rule by MB. For the latter group, or at least for some of them, army intervention would constitute the "corrective revolution" that would take the country along the path of the slogans of the January revolution, which the MB had abandoned in their eyes. For the army's leaders, it was the proper moment to give power back to army officers, some of whom had taken power in July 1952, in the belief that power should never again be left to civil groups.

The third idea, which was particularly influential among the revolutionary young people, was the social-democratic ideal embodied in the slogan of the January Revolution (bread, liberty, social justice and human dignity). However, this ideal ceased to be attractive to the masses, or was reduced by them to the notion of democracy, understood not as a particular way of exercising power, but as a promise of decent living, the alleviation of poverty, and adequate social services. The difference between the young revolutionaries and the larger masses was that the former did not see army rule as the vehicle to promote social justice and democracy. The latter did not see any contradiction between democracy as they understood it and army rule. After all, it was Gamal Abdel Nasser, an army officer, who had brought a measure of social justice to the country following the July 1952 Revolution. Another army officer could do the same in July 2013.

Thus, both the Egyptian public's lack of popular resistance towards authoritarian tendencies and its lack of support for revolutionary young people can perhaps be explained by its specific understanding of democracy, as shown by several surveys carried out between 2011 and 2014. ${ }^{26}$ The public understood democracy, according to Arab Barometer II, as economic well-being and social justice. The World Values Survey introduced a distinction between two cultural orientations, one stressing importance of survival and maintaining tradition, and another stressing self-expression. The latter is more favorable to emancipation and democracy. Egypt, along with other Muslim countries, tends to be closer to the first orientation, but in other Muslim countries, the "Muslim-Non-Muslim

26. Gawad, G. A. et al. 2011, http://www.worldvaluessurvey.org/WVSdocumentation. WV6.jsp.2008). 
gap over emancipation values closes" due to higher education and "especially among young Muslim women with higher education." ${ }^{27}$

\section{REFERENCES}

\section{Documents}

Arab Republic of Egypt, Constitution of the Arab Republic of Egypt, 2012 [in Arabic]. ARE, Constitution of the Arab Republic of Egypt, 2014 [in Arabic].

Presidency of the Republic, Constitutional Declaration, August 11, 2012 [in Arabic]. Presidency of the Republic, Constitutional declaration, November 22, 2012 [in Arabic]. Presidency of the Republic, Constitutional Declaration of the Interim Period, July 6, 2013 [in Arabic].

Supreme Council of the Armed Forces, Constitutional Declaration, March 30, 2011 [in Arabic].

SCAF, Supplementary Constitutional Declaration, June 16, 2012 [in Arabic].

SCAF, Statement of the Armed Forces, July 3, 2013 [in Arabic].

Decree Law $n^{\circ} 107$ on organizing the right to public meetings, November 24, 2013. Law $n^{\circ} 46$ on the House of Deputies, June 5, 2014.

Law $\mathrm{n}^{\circ} 22$ on presidential elections, March 8, 2014.

Decree law $n^{\circ} 8$ on terrorist entities and terrorists, February 17, 2015.

\section{Books}

El-Selmi, A. 2013, Protected Egypt. Revolution to Victory, Cairo: Sama [in Arabic]. Evans, P. et al. 1985, Bringing the State Back. New York: Cambridge University press. Hammad, A. 2014, Revolution at a Loss. Conflict of Helmet, Chin and the Square. Eyewitness View, Cairo: Al-Mahrousa, 2nd edition [in Arabic].

Hattam, V. 1993, Labor Visions and State Power: The Origins of Business Unionism in the United States, Princeton: Princeton University Press.

Immergut, El. 1992, Health Politics: Interests and Institutions in Western Europe, New York: Cambridge University Press.

Kandil, H. 2016, The Power Triangle. Military, Security and Politics in Regime Change, Oxford, London \& New York: Oxford University Press.

Krasner, S. 1980, Defining the National Interest. Princeton: Princeton University Press.

Rab`i Amr Hashem (ed.), People's Assembly Elections 2011/2012, Center for Political and Strategic studies, Cairo: Al-Ahram, 2012 [in Arabic].

Schweers Cook, K. and Levi, M. (eds), 1990, The Limits of Rationality, Chicago: Chicago University Press.

Swidler, A. 1986, "Culture in Action: Symbols and Strategies", American Sociological Review, $\mathrm{n}^{\circ}$ 51, p.273-286.

27. WVS, 6. Ibid. 


\section{Articles}

Brown, N. and Dunne, M. 2013 "Egypt's Draft Constitution Rewards the Military and Judiciary", Carnegie Endowment for International Peace, December 4.

Brown, N. 2013, "Egypt's Failed Transition", Journal of Democracy, Vol. 24, № 4, October, p.45-58.

—. 2012, "Morsi's Ramadan Surprise", Carnegie Endowment for International Peace, August 13.

Brown, N. and Lombardi, C. 2012, "Islam in Egypt's New Constitution", Foreign Policy, December 13.

Hall, P. and Taylor R. 1996, "Political Science and the Three New Institutionalisms", MPIFG Discussion Paper, vol. 96, n 6, June.

Kandil, H. 2016, "Sisi's Egypt", New Left Review, n 102, November-December, URL: http://www.newleftreview.org/ll/102/hazem-kandil-sisi--s-egypt.

Kouedi, M. 2013, "From Morsi with Love", Sada. Carnegie Endowment for International Peace, March 12.

Sayigh, Y. 2012, "Above the State: The Officers Republic in Egypt", Carnegie Endowment for International Peace, August 1, 2012.

— . 2015, "The Return of Egypt's Military Interest Groups". Diwan. Carnegie Endowment for International Peace, December 21.

Steuer, C. and Blouet, A. 2015, "The Notions of Citizenship and the Civil State in the Egyptian Transition Process," Middle East law and Governance, Vol. 7, n 2, p.236-256

\section{Public opinion polls}

Soltan Gawad Abdel, G., Quamha Nagui, A. and Asilah, S. 2011, The Arab Barometer Project II, Arab Republic of Egypt, Cairo: Center for Political and Strategic Studies, June.

World Values Survey, Wave 6, 2010-2014, URL : http://www/worldvaluessurvey.org/ WVSOnline.jsp 